\title{
Sex Steroid Hormones and Tumors in Domestic Animals
}

\author{
Yolanda Millán, Silvia Guil-Luna, Carlos Reymundo, \\ Raquel Sánchez-Céspedes and \\ Juana Martín de las Mulas
}

Additional information is available at the end of the chapter

http://dx.doi.org/10.5772/54324

\section{Introduction}

Sex steroid hormones play a role in the development and control of animal tumours, particularly in those arising in their target organs. Due to their incidence and prevalence, mammary tumours of female dogs and cats are among the most frequently studied with focus on the role of ovarian oestrogen and progesterone. In these tumours, sex steroid hormones have been shown to act during the three steps of the carcinogenesis cascade: initiation, promotion and progression. Experimental data have shown the mutagenic effect of oestrogens [1] while epidemiologic and clinical studies highlighted the role of ovarian hormones as promoters on mammary tumours in both the dog and the cat [2-9]. Finally, oestrogens and progesterone further act during tumour progression. Their role in the last two steps of carcinogenesis makes it possible to control the evolution of the disease.

Studies on the role of ovarian hormones during tumour progression depend on the capability of demonstrating the presence of oestrogen receptors (ER) and progesterone receptors (PR) in tumours. Earlier studies on the field were published in the seventies of the $20^{\text {th }}$ century, all related to mammary gland tumours. Some of these studies revealed the presence of unoccupied hormone receptors in tissue homogenates from mammary tumours of dogs and cats [10-13]. However, actual knowledge comes from the late nineties, when different groups of researchers standardized immunohistochemical (IHC) methods of analysis for ER and PR in feline and canine tissues [14-19]. Once the IHC analysis revealed the presence of sex steroid hormones receptors in mammary tumours, several studied analyzed their value as favourable prognostic indicators $[18,20-25]$ adding new data to the well-known similari- 
ties between and human and animal mammary tumours [26]. However, the important role of ER and PR as predictive factors of response to endocrine treatment of breast cancer has been rarely analyzed in animal tumours although recent studies based on the blockade of PR in canine mammary carcinomas and reproductive tract tumours of female and male dogs and cats support their value in the control of these diseases [27-30].

Mammary gland tumours are the most frequent tumours in female dogs and the third in the cat. However, they are not the only tumours known to be sex steroid-dependent. Tumours of the reproductive tract of female and male dogs and cats and some skin appendages can be defined as hormone-dependent on the basis of the IHC expression of ER $\alpha$ and PR [31, 32]. In addition, epidemiological and clinical studies support the role of steroid hormones as tumour promoters [28]. The most common tumours in the genital tract of the bitch are benign smooth muscle tumours of the vagina, vulva and perineal skin. Their hormone-dependence is similar to that of mammary gland tumours as the majority of canine genital tract leiomyomas express PR and also respond to neoadjuvant treatments with the PR antagonist aglepristone with a reduction in size [28].

In the dog, and to a lesser extent in the cat, benign and malignant sebaceous gland neoplasias are among the most common skin tumours. Studies concerning the role of sex steroid hormones during tumour promotion and progression are scarce but do show there is ER and PR expression in sebaceous gland tumours of dogs. Therefore, not only androgens but also progesterone and estrogens may regulate hormone-related physiology. In fact, preclinical studies indicate partial clinical remission after chemical castration in old dogs with hepatoid gland tumours and heart failure [30].

\section{Methods for studying steroid hormone receptors}

Immunohistochemical (IHC) methods based on antigen-antibody reactions are widely used today to detect steroid hormone receptors in tumours. New specific antibodies have been developed against a range of steroid hormone receptors, enabling reliable detection by ordinary light microscopy. Traditionally, however, steroid hormone receptors were detected by biochemical assay based on the binding of radiolabelled ligands to unoccupied receptors. Among the most commonly used biochemical techniques was the dextran-coated charcoal (DCC) method [33], which - until the late nineties - provided all the data available on steroid hormone receptor expression in mammary carcinomas in female domestic animals. Biochemical techniques, however, were not without drawbacks: they had to be applied to frozen tissue samples, were very expensive, needed specialised equipment and were not widely accessible. For this reason, published research on the use of these techniques was scanty. The development of monoclonal antibodies highly specific to oestrogen receptor $(\mathrm{ER} \alpha)$ and progesterone receptor (PR) proteins enabled the development of immunohistochemical techniques based on the binding of receptors to specific antibodies [34-37]. These techniques offered several major advantages over biochemical methods [38-40]: 
1. They could be applied to tissue samples routinely processed for histopathology and could be performed in the pathology laboratory, rendering them both more accessible and less costly.

2. They provided information regarding the specific location of ER and PR, enabling analysis of the relationship between receptor expression and tissue structures in normal and/or tumoural mammary glands, thus avoiding the false-positive findings common in biochemical examinations.

3. They furnished information on all the receptors present in tissue samples, irrespective of the occupation status.

The process of standardizing IHC methods of ER and PR detection in animal tissues involved the use of commercially available antibodies raised against human antigens first as antibodies raised against canine and feline antigens were not produced. Then, these IHC methods for detecting ER and PR in formalin-fixed, paraffin wax-embedded tissue samples needed to be validated before they could be routinely implemented, as stipulated by the "National Institutes of Health Consensus Conference on Estrogen Receptors in Breast Cancer" (NIHCC), held in 1979. The first step in the validation procedure was the comparison of ER and PR detection using both biochemical and IHC techniques and the correlation of IHC results with those of the gold-standard radioligand-binding assays in order to evaluate their specificity and sensitivity. In 1999, Graham et al. [15] analysed ER $\alpha$ expression in formalinfixed, paraffin-embedded tissue samples from canine mammary tumours using biochemical and IHC methods, reporting good correlation between the two. In 2000 and 2002, Martín de las Mulas et al. $[17,19]$ validated the IHC method for the detection of ER $\alpha$ and PR detection, respectively, in formalin-fixed, paraffin-embedded tissue samples from feline mammary tumours using the avidin-biotin-peroxidase complex (ABC) method, and compared their findings with those obtained using the DCC biochemical method; reported agreement between the two methods was $72.7 \%$ for ER $\alpha$ and $95.6 \%$ for PR. The IHC technique used demonstrated good specificity (true-negatives) and sensibility (true-positives) (Table 1).

\begin{tabular}{ccc}
\hline DCC versus IHC & ERa & PR \\
\hline SPECIFICITY & $95.6 \%$ & $89.4 \%$ \\
\hline SENSIBILITY & $47.6 \%$ & $87.5 \%$ \\
\hline
\end{tabular}

Table 1. Specificity and sensibility of an IHC method for detecting ER and PR, versus a biochemical method (DCC) in feline mammary carcinomas $[17,19]$.

Second, the NIHCC (1979) also recommended the clinical validation of technically validated IHC methods since the presence of ER and/or PR in human breast cancer was known to be a favourable prognostic indicator as well as a predictive marker of the response to adjuvant hormone therapy [41, 42]. The prognostic value of the IHC expression of ER $\alpha$ and PR expression in canine mammary carcinoma has been demonstrated in the dog and the cat [18, 
20-25]. Finally, preclinical and clinical studies of our group have shown that the PR antagonist Aglepristone produces partial clinical remission of canine mammary carcinoma [29].

At present, IHC methods are routinely used in a number of veterinary laboratories for the detection of ER and PR. However, no consensus has yet been reached regarding tissue preparation, the antibodies and techniques to be used, and the evaluation of results. New image-analysis systems may help to objectively evaluate receptor expression and to standardise the results obtained by different pathologists [43]. The guidelines issued by the American Society of Clinical Oncology/College of American Pathologists to improve the accuracy of immunohistochemical ER $\alpha$ and PR testing in breast cancer and their utility as predictive markers of the response to hormone therapy may serve as a model for veterinary pathologists [44].

\section{Mammary gland tumours in dogs and cats}

Mammary gland tumours are the most common neoplasms in female dogs and the third most common in female cats, but are rare in other domestic animals. Between $41 \%$ and $53 \%$ of mammary tumours in dogs and between $85 \%$ and $93 \%$ in cats are malignant. Most authors agree that these tumours account for around $50 \%$ and $17 \%$ of all neoplasms in dogs and cats, respectively, with an incidence of 205 and 25.4 per 100.000 dogs and cats at risk. Median age at tumour presentation is 10-12 years in both species [45]. Tumours develop almost exclusively in females, appearing only rarely in males [46-48]. Breed is also a risk factor: mammary tumours are more common in pure-bred than in mixed-breed animals, and some breeds - including Poodles, Boxers, Beagles, a number of Spaniel breeds, and Siamese cats - display a higher incidence than others [45, 49-51]. Other risk factors are more controversial, or have been the subject of less research: diet, exposure to radiation, family background and individual history of benign and malignant mammary lesions. The action of ovarian hormones - oestrogens and progesterone - on mammary gland tissue during different stages of development is also a risk factor associated with the development of mammary tumours, while breeding-related factors such as parity, age at first gestation, number of pregnancies, pseudopregnancy and changes in the oestrous cycle, do not appear to influence the risk of developing mammary tumours, although not all authors agree on this [45].

The development of mammary tumours in female dogs and cats is clearly hormone-dependent, and they offer a good spontaneous model of human breast cancer. The preventive effects of castration on the development of mammary tumours in both species have been reported [52-54]. Early ovariectomy in dogs and cats has a protective effect against both benign and malignant mammary tumours, the intensity of that effect depending on the number of cycles before spaying. In dogs spayed before the first oestrus, the risk of developing a mammary tumour is $0.05 \%$, compared to $8 \%$ after the first oestrus and $26 \%$ after the second oestrus; the protective effect of spaying disappears after the age of 2.5 years. In cats, spaying before 6 months of age reduces the risk of mammary carcinoma by $91 \%$ with respect to unspayed cats, while spaying before 1 year of age cuts the risk by $86 \%$. 
While prolonged administration of oestrogens has not been shown to increase the incidence of mammary tumours [55,56], administration of medroxyprogesterone acetate and progestins over a prolonged period to young female dogs increases the risk of mainly benign mammary tumours; the intensity of that risk depends on the dosage received and on the regularity or irregularity of treatment [6]. A number of authors, however, also report an increased incidence of malignant tumours [7]. The risk of developing a malignant tumour rises following long-term experimental administration of oestrogens combined with high-dose progestins as shown by experimental studies to analyze the effects of the pill $[55,57]$, and following the administration of drugs with combined progestagenic-oestrogenic activity to control the signs of oestrus [6-9]. Thus, prolonged administration of high-dose (125 x human dose) of a progestational compound (lynestrenol) prompted the development of breast cancer in $40 \%$ of intact treated dogs [6]. By contrast, a combined regime of low-dose progestagen+oestrogen appears to afford some protection [6]. Cats treated with synthetic progestins or oestrogen-progestin combinations displayed a threefold higher risk of developing benign and malignant mammary tumours than untreated cats [58].

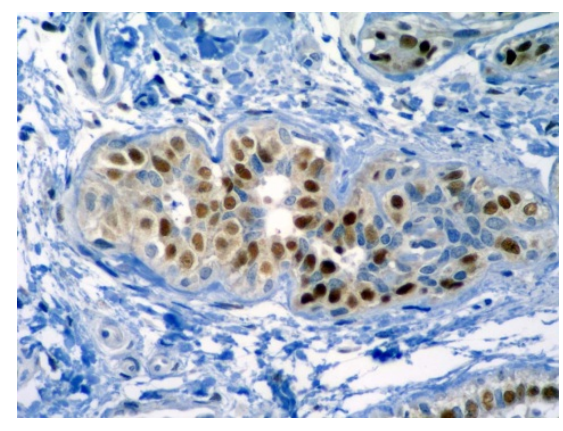

Figure 1. Details of a canine simple carcinoma showing expression of ERa in the nucleus of luminal epithelial cells (brown colour). ABC. 40X.

The role played by ovarian steroid hormones during tumour progression (i.e., once the tumours are detected clinically) has been studied through their expression of ER $\alpha$ and PR. Early studies using biochemical methods of ER $\alpha$ and PR analysis showed that between $65 \%$ and $92 \%$ of mammary tumours contain hormone receptors [17, 19]. With IHC methods, differential expression between benign and malignant tumours has been observed in dogs and cats as the expression was higher in the former. However, data concerning ER $\alpha$ expression in mammary carcinomas are very different among different laboratories. Thus, in the dog, $7 \%$ [59], 10\% [16], 11\% [14], 22\% [20], 24\% [15], 59\% [60, 61], 87.5\% [18] and $92.6 \%$ [62] of canine mammary carcinomas have been shown to express ER $\alpha$ (Figure 1). Concerning PR expression, reported data are the following: 14\% [63], 33\% [14], 42\%-52\% [62, 64], 60\% [16] and $66 \%$ [20](Figure 2). In the cat, $7 \%$ and $17 \%$ of in situ carcinomas expressed ER $\alpha$ and PR, respectively [59] while invasive carcinomas expression figures range from $10 \%$ [65] to $25 \%$ [17] for ER $\alpha$ and from $38.5 \%$ and $43 \%$ for PR [19, 65]. Many of these studies point to proges- 
terone, and not oestrogens, as the sex steroid hormone driving proliferation in mammary gland tumours as all benign tumours of the canine mammary gland and 2/3 of malignant tumours express PR [14, 16, 20, 22].

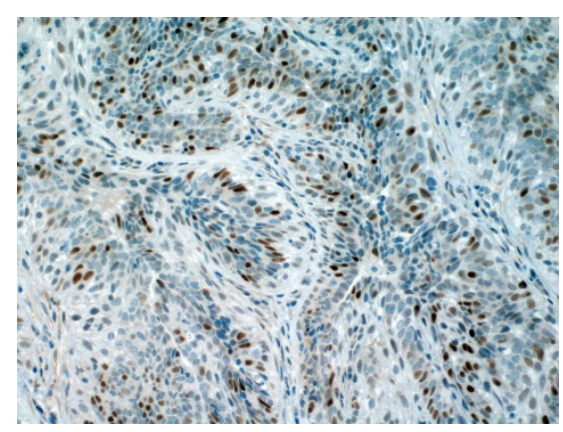

Figure 2. Canine simple carcinoma showing PR expression in the nucleus of neoplastic epithelial cells. (brown colour). ABC. 20X.

After the cloning of a second ER in rats and humans, designated ER $\beta[66,67]$, it became known that currently reported data correlated with the isoform $\alpha$ of ER (ER $\alpha)$. Our group was the first to publish data on the expression of the second isoform of the ER (ER $\beta$ ) in mammary tissues of dogs [68], and one more study has been performed up to date [69]. ER $\beta$ expression was observed in the ductal and acinar epithelium of normal mammary glands and in one third of mammary tumours. Expression was greater in benign than in malignant tumours [68]. Among malignant tumours, ER $\beta$ expression was greater in complex and mixed tumours than in simple carcinomas, indicating that ER $\beta$ may also be a prognostic factor of these tumours (Figure 3).

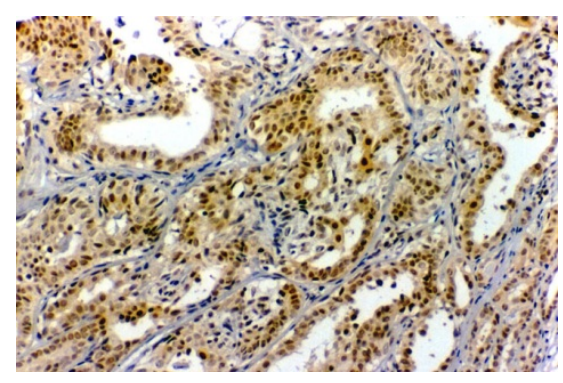

Figure 3. ERß immunoreaction in the nucleus of neoplastic epithelial cells of canine mammary carcinoma. ABC. 20X.

The prognostic value of steroid hormone receptor activity in malignant tumours (lower risk of relapse and metastasis, together with greater survival time) is now widely accepted after several univariate and multivariate prognostic studies using IHC methods for detection of ER and PR [18, 20-25]. In a study using IHC techniques to detect ER and PR expression in 
228 tumours (155 malignant and 73 benign) from 100 bitches, Martín de las Mulas et al. [20] found that a total of $76 \%$ of tumours ( $96 \%$ benign and $66 \%$ malignant) expressed ER $\alpha$ and/or PR. In seven cases with lymph node metastasis, both the primary tumours and their metastases were ER $\alpha$ and PR negative, indicating a loss of hormone influence and thus greater aggressiveness. Expression of PR alone in $66 \%$ of malignant tumours suggested that PR played a more important role than ER $\alpha$ in tumour proliferation.

Surgery is the treatment of choice for feline and canine mammary tumours. Treatment with drugs such as tamoxifen has been tested in dogs with mammary carcinoma, but is not recommended due to their considerable side effects; these drugs are therefore not currently in use [70]. Ovariohysterectomy (OHE) performed at the time of surgery does not appear to produce any clear benefit in dogs with mammary carcinoma [71, 72]. The only adjuvant treatment administered at present is chemotherapy, and results are not wholly satisfactory [45].

In 1998, Cappelletti et al. [73] reported different ER $\alpha$ and PR counts in tumours analysed before and after treatment with a range of drugs including tamoxifen, concluding that malignant mammary neoplasms were sensitive to steroid hormone treatment. A feline dysplasia of the mammary gland, the feline fibroadenomatous change, is highly sensitive to Alizin ${ }^{\circledR}$, a PR antagonist [74, 75]. The fact that all benign tumours and two thirds of malignant tumours in dogs express mainly PR [16, 17, 22] points to the potential use of progesterone receptor antagonists as a neoadjuvant and/or adjuvant treatment for these tumours. A recent study performed by our group [29] has shown that administration of the PR receptor antagonist Aglepristone (Alizin $®$, Virbac, France) as neoadjuvant treatment in female dogs inhibits the proliferation of PR-expressing mammary carcinomas. Twenty-seven non-spayed bitches with mammary tumours were treated with Alizin ${ }^{\circledR}$ before surgical tumour removal. Tumour tissue samples were analysed before and after treatment, and PR expression was reduced following treatment ( $36.4 \%$ versus $59.1 \%$ prior to treatment). The proliferative index (PI) was also analysed before and after treatment, using the avidin-biotin-peroxidase complex technique and a proliferative marker (Ki67). A significant decrease in the PI was recorded in tumours expressing PR, while no change was observed in those not expressing PR, suggesting that the PR antagonist Aglepristone inhibited tumour proliferation in PR-positive tumours by blocking the PR.

\section{Female and male reproductive-tract tumours in dogs and cats}

\subsection{Female reproductive tract}

The actual incidence of female reproductive-tract tumours is difficult to ascertain, presumably because a significant percentage of dogs and cats are neutered [76]. These tumours may arise in the vagina, vulva, uterus or ovaries; vulvar and vaginal tumours are the most common (after mammary gland tumours), accounting for $2.4 \%$ to $3 \%$ of all canine neoplasms $[77,78]$. No incidence rates are available for vulvar and vaginal tumours in cats. Uterine tumours are rare in both dogs and cats, accounting for $0.3 \%-0.4 \%$ and $0.2 \%-1.5 \%$ of all canine 
and feline tumours, respectively [77, 79-84]. Ovarian tumours are also uncommon in dogs and cats; although the true incidence is unknown, the reported incidence in intact bitches is $6.25 \%$, thus representing $0.5 \%$ to $1.2 \%$ of all canine tumours [85, 86], while reported incidence in cats ranges from $0.7 \%$ to $3.6 \%$ [87]. The most common neoplasms in the canine female reproductive tract are benign tumours of mesenchymal origin, classified as leiomyomas, fibroleiomyomas, fibromas and polyps depending on the amount of connective tissue present $[88,89]$. The use of markers for smooth-muscle differentiation (e.g. desmin, calponin, smooth muscle actin) is valuable for the accurate identification of smooth muscle involvement in tumour growth [31, 90, 91] (Figure 4).

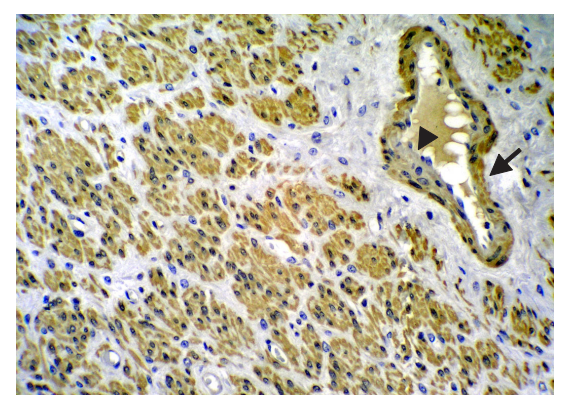

Figure 4. Immunohistochemical detection of the smooth muscle protein calponin in a leiomymoma. Most of the tumour cells show immunoreactive products to calponin antibody in their cytoplasms (brown colour). The vascular smooth muscle cells are also reactive (arrow) while endothelial cells are unreactive (arrowhead). ABC. 20X.

Leiomyoma is among the most common tumours of the female reproductive tract in many domestic species. It is located primarily in the vulva and vagina, followed by the uterus and its incidence is greater in older non-neutered bitches [77, 78]. In two different studies, all dogs diagnosed with leiomyoma were non-neutered bitches $[78,93]$ and the recurrence rate was $15 \%$ in bitches left unneutered after local excision. On the contrary, there was no recurrence in any animal when ovariohysterectomy was performed at the same time as excision. In another study [77], no leiomyomas were diagnosed in ovariectomised bitches under two years old. These epidemiological and clinical findings support the hormone-dependent nature of leiomyomas [88]. In addition, the role of ovarian steroid hormone receptors in the progression of female reproductive tract leiomyomas in the dog has also been demonstrated. Thus, Millán et al. [31] performed the first study on canine leiomyomas from the reproductive tract (uterus, vagina and vulva) demonstrating the IHC expression of ER $\alpha$ and PR in tumour tissue samples. Half of the leiomyomas (50\%) expressed ER $\alpha$ and more than three quarters (82.1\%) expressed PR (Figure 5).

Finally, a pioneer study of our group reported that the expression of PR in a canine vaginal fibroma was a predictive factor of favourable response to hormone therapy. Aglepritone at a dose of $10 \mathrm{mg} / \mathrm{kg}$ injected at days 1, 2, 8, 15, 28 and 35 prompted a progressive reduction in the size of the mass, which measured $9.1 \times 5.4 \mathrm{~cm}$ on day 1 and $6.4 \times 4.7 \mathrm{~cm}$ on day 45 [28] (Figure 6). The authors evaluated the proliferation index in the same study using a prolifera- 
tion marker (Ki67), recording similar low values at days 15 and 25 of treatment, suggesting that Aglepristone did not reduce tumour size by reducing the tumour cell proliferation rate but rather through increasing apoptosis. It was therefore concluded that the size of PR-expressing benign tumours of the canine vagina could be reduced by palliative or neoadjuvant therapy with the PR antagonist Aglepristone. These findings regarding steroid hormone receptor expression in canine tumours of the female reproductive tract highlight the potential of hormone therapy in selected cases. In cats, leiomyomas located in the mammary gland and in the perineal region are reported to express ER $\alpha$ and PR [27]; however, no research has yet focussed on the expression of steroid hormone receptors in feline leiomyomas located in the vagina, vulva or uterus.

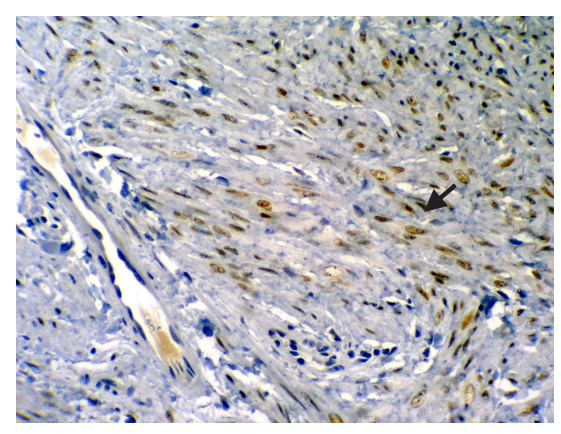

Figure 5. Immunohistochemical detection of ERa in a leiomyoma. Most of the tumour cells show immunoreactive products to ER antibody in their nucleus (brown colour)(arrow). ABC. 40X.
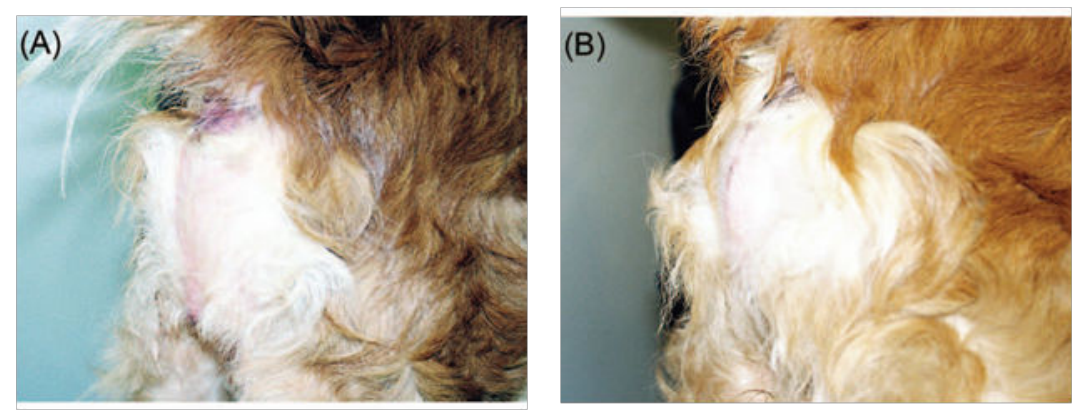

Figure 6. A) Female dog with a perineal mass measuring $9.1 \times 5.4 \mathrm{~cm}$. (B) The appearance of the tumour mass 28 days after treatment with aglepristone. The size is reduced to $6.4 \times 4.7 \mathrm{~cm}$ [28].

\subsection{Male reproductive tract}

Male reproductive-tract tumours in dogs and cats may arise in the testes, prostate, penis or foreskin. Testicular tumours are the second most common cancer in intact dogs, accounting 
for roughly $90 \%$ of all reproductive-tract tumours [96]. In cats, however, testicular tumours are rare [97]. Prostate tumours are uncommon in dogs, with a reported incidence of between $0.2 \%$ to $0.6 \%[98,99]$, and equally rare in cats [97, 100-102]. Many penis and foreskin tumours affect the epithelial surface of these structures, the most common being the transmissible venereal tumour of the penis in dogs [103].

Currently, the only male reproductive-tract tumour in domestic species for which published data is available regarding the possible influence of steroid hormones on tumour development is canine prostate carcinoma. The dog is the only non-primate species that develops spontaneous prostate cancer [104]. Most tumours in this location are of epithelial origin [98, 105] and mainly affect older dogs (average age 10 years), prostate carcinoma being common [98]. The prostate is an androgen-dependent organ [106], and androgens achieve their effect through activation of androgen receptors (AR). However, there is a good deal of controversy concerning the influence of androgens on the development and biological behaviour of malignant prostate tumours. While some studies have found no evidence that castration has a protective effect against prostate carcinoma [99], others argue that castration before sexual maturity reduces the risk of this malignancy [105]; still others suggest that castration may actually increase the incidence and aggressive behaviour of canine prostate carcinomas [98]. The expression of steroid hormone receptors in tumour tissue samples of canine prostate carcinoma has been rarely studied. The more complete study up to date showed that expression of AR, ER $\alpha$ and ER $\beta$ was lower in malignant tumour epithelial cells than in normal prostate tissue and benign lesions, suggesting that oestrogen actions in the prostate are complex and may play a dual role in the aetiology of prostate cancer $[32,107]$. This study also demonstrated for the first time that PR expression in canine prostate tumours is greater than in normal prostate tissue [32], although the effect of progesterone at this location still remains to be demonstrated, as does the potential for hormone therapy.

\section{Cutaneous tumours in dogs and cats}

Tumours of the skin and subcutaneous tissue are the most common neoplasms affecting dogs and the second most common in cats [108]. Incidence rates have been estimated at around 450 per 100,000 dogs and 120 per 100,000 cats [108]. In dogs, most skin tumours are benign, the most frequent being histiocytomas and sebaceous gland adenomas. In cats, however, approximately $50 \%$ to $65 \%$ of skin tumours are histologically malignant, the most frequently-reported being squamous cell carcinomas [109].

Epidemiological research has identified breed and age as major risk factors for these tumours. A number of authors note a linear increase in risk by a factor of 1.1 per year of increasing age; additionally, pure-bred dogs appear to be twice as likely to develop a malignancy as cross-breeds. When all types of tumours are considered together, no significant sex predilection is apparent [110]. A number of etiological factors - physical, viral, genetic and molecular - have been reported for some skin tumours [111]. Over the last few years, it has become increasingly evident that steroid sex hormones may play an 
important role in the pathogenesis of these tumours, as they do in mammary tumours. It is well known that oestrogens, progesterone and androgens not only help regulate skin development and function, such as the development and/or physiology of sebaceous glands and hair follicles, but are also involved in the development and biological behaviour of certain skin neoplasms [112].

To date, a number of studies have demonstrated a possible relationship between sex steroid hormones and sebaceous, perianal and hepatoid gland tumours and mast-cell tumours in domestic animals. To better understand this relationship, recent research has focussed on pinpointing the site of action of these hormones and on locating their receptors in both normal and tumour tissues. As a result, biochemical and immunohistochemical studies carried out over the last few years have detected androgen receptors (AR), oestrogen receptor $\alpha$ $(\mathrm{ER} \alpha)$ and progesterone receptors (PR) in epidermis, hair follicles and fundamentally in the sebaceous glands of canine skin [113-117]. These results suggest that not only androgens and oestrogens, but also progesterone, may play a major role in the regulation of normal skin appendage function and in the pathogenesis and development of neoplasms.

Sebaceous gland tumours are among the most common skin tumours in the dog. They can be divided into four groups based on histological appearance: sebaceous hyperplasia, sebaceous epitheliomas, sebaceous adenomas and sebaceous adenocarcinomas. They account for between $6.8 \%$ to $7.9 \%$ of all skin tumours in dogs, and between $2.3 \%$ to $4.4 \%$ in cats [118]. Canine benign and malignant sebaceous gland neoplasias may provide a suitable experimental model for the study of hormone influences on the development of glandular tumours [114]. As in human skin, specific staining for ER $\alpha$ and PR is seen mainly in the basal cells of normal sebaceous glands [115-117]. However, unlike in human medicine, no data are available regarding the possible involvement of these steroid sex hormones in the pathology of canine and feline skin and the development of cutaneous neoplasms. A single study by the present authors analysed ER $\alpha$ and PR expression in canine sebaceous gland hyperplasias, adenomas/epitheliomas and carcinomas [117], revealing that canine sebaceous glands express both ER $\alpha$ and PR (Figure 7 y 8). Moreover, differences were recorded between types of lesion in the number of cells expressing ER $\alpha$ and PR. Compared with normal sebaceous glands, ER $\alpha$ expression was significantly lower in sebaceous gland epitheliomas and adenocarcinomas, suggesting that ER $\alpha$ plays a key physiological role in the maintenance of normal sebaceous glands, and that a decrease in levels influences the development of both benign and malignant neoplasms. A number of studies indicate that this drop in ER $\alpha$ could be secondary to changes in androgen or oestrogen production, but further research is required to confirm this hypothesis in canine sebaceous glands. The cited study also found that PR expression in adenocarcinomas was significantly lower than in normal and hyperplastic sebaceous glands, suggesting that tumour growth may become less hormone-dependent during the progression phase of carcinogenesis, as reported in certain human mammary tumours. Unlike ER $\alpha$, the proportion of PR-positive cells did not differ significantly from that found in normal sebaceous glands, a finding also reported in humans [112]. This may indicate that progesterone does not necessarily influence the growth of this type of tumours. Conversely, sebaceous gland carcinomas display a significant loss in PR staining 
intensity; PR loss may be one factor involved in the pathogenesis of canine sebaceous gland neoplasms.

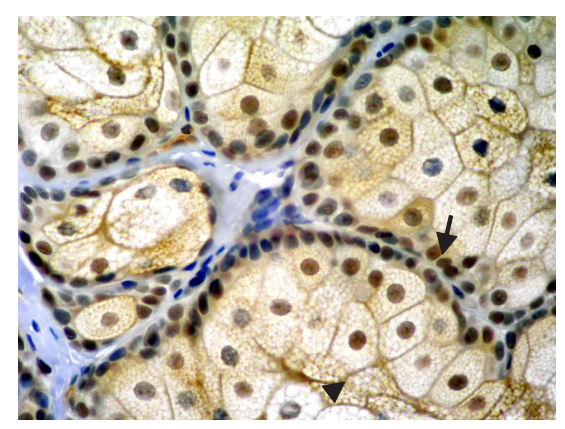

Figure 7. Immunohistochemical localization of PR in sebaceous gland hyperplasia. Nuclear staining is observed in basal cells (arrow) and differentiated sebocytes (arrowhead) [117]. ABC. 40X.

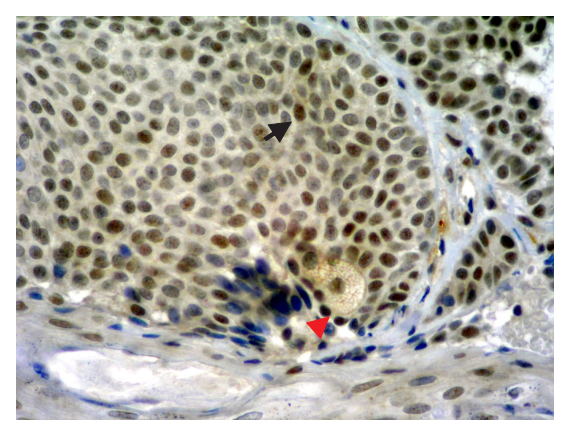

Figure 8. Immunohistochemical localization of PR in a sebaceous gland epithelioma. Nuclear staining is observed in basal cells (arrow) and differentiated sebocytes (arrowhead) [117]. ABC. 40X.

The influence of female sex steroids on their receptors in skin has been highlighted by several studies. When an ovariectomised bitch received a local estradiol (E2) implant, ER levels in the affected skin were found to be six times higher than in control skin [119]. However, despite the considerable amount of work done to date in this field, further research is still required to demonstrate the presence of AR and examine of the effects of these hormones and their pharmacological antagonists on tumour development.

Other tumours considered clearly hormone-dependent include those arising in the perianal or hepatoid glands, modified sebaceous glands located in the perianal dermis. The most frequently observed tumours of this region in dogs are perianal adenoma, perianal adenocarcinoma and apocrine gland adenocarcinoma of the anal sac. Perianal adenomas account for between $58 \%$ and $96 \%$ of all canine perianal tumours [120]. Unlike adenomas, perianal gland carcinomas are rare, accounting for between $3 \%$ and $17 \%$ of all per- 
ianal neoplasms [121]. Although found in both male and female dogs, the highest incidence is reported in intact males of mean age 10 or more [122]. This evidence has for years been interpreted as proof of a clear stimulation of tumour development by sex steroid hormones, particularly androgens [123]. Adenomas have been found to be hormoneresponsive; a full or partial regression has been observed following castration or oestrogen treatment [113, 120, 124]. In females, perianal adenomas occur almost exclusively in ovariohysterectomised animals whose low oestrogen levels fail to suppress tumour growth. Similarly, testicular interstitial cell tumours - which clinical observation suggests are associated with an increase in systemic androgen levels - occur more frequently in association with perianal tumours [125]. While hormone dependence has been clearly demonstrated in the case of perianal adenomas, there appears to be no link between perianal adenocarcinomas and steroid sex hormones. Perianal gland carcinomas do not regress following castration and are not responsive to hormone therapy with oestrogens [121, 124]. However, receptors for these hormones have been found in normal, hyperplastic and neoplastic perianal glands in dogs (Figure 9). An early report identified androgen-binding sites in perianal adenomas [124]. Research by Pisani et al. [126] detected AR expression in all normal and abnormal glands, although in hyperplastic tissues the proportion of positive nuclei was significantly greater than in normal tissue. A similar increase in the percentage of positive-staining nuclei was also observed in perianal epitheliomas, while in adenomas the increase with respect to normal tissue was only slight. In adenocarcinomas, the proportion of AR-positive cells was similar to that observed in benign tumours.

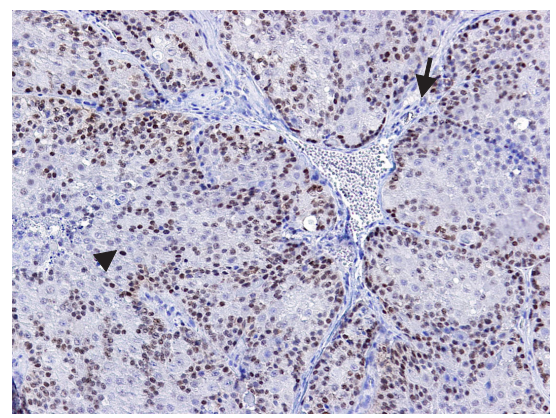

Figure 9. Immunohistochemical localization of ERa in a hepatoid gland adenoma. Nuclear staining is observed in basal cells (arrow) and differentiated hepatoid cells (arrowhead). ABC. 20X.

All these observations support the view that therapy based on antagonists of these hormones could prove beneficial in the treatment of these tumours. The present authors have carried out a preliminary clinical trial in order to evaluate the effect of Deslorelin (Suprelorin $^{\mathrm{TM}}$ Virbac), a GnRH antagonist, on the clinical response of perianal gland adenomas [127]. This antagonist suppresses pituitary production of the hormones LH and FSH and of steroid sex hormones; its effect has been compared to that of surgical castration. The trial found that 
subcutaneous deslorelin implants induced complete remission in at least $50 \%$ of dogs and a partial response to treatment in a further $29 \%$. This antagonist could thus be considered as a new option for the treatment of perianal gland adenomas.

Finally, the association between mast-cell tumours (MCTs) and steroid sex hormones remains controversial. The role of these hormones in tumour pathogenesis is poorly understood, although some evidence is now available: one study has detected cytosolic receptors for oestrogen and progesterone in canine MCTs [127], while another found that 6 out of 9 MCTs contained no ER $\alpha$ and 3 were questionable [128].

\section{Conclusion}

Sex steroid hormones are involved in the development of animal tumours with high epidemiological and clinical impact. Research in the field has shown the potential benefits of endocrine manipulations to control tumour progression in a neoadjuvant or adjuvant setting. From a comparative point of view, steroid hormone dependent animal tumors represent an accessible and natural model of human disease.

\section{Author details}

Yolanda Millán*, Silvia Guil-Luna, Carlos Reymundo, Raquel Sánchez-Céspedes and Juana Martín de las Mulas

*Address all correspondence to: an2mirum@uco.es

Department of Comparative Pathology, University of Córdoba, Córdoba, Spain

Yolanda Millán and Silvia Guil-Luna are equal first authors

\section{References}

[1] Ahern TE, Bird RC, Church Bird AE, Wolfe LG: Expression of the oncogene c-erbB-2 in canine mammary cancers and tumor-derived cell lines. American Journal of Veterinary Research 1996;57 693-696.

[2] Dorn CR, Don T, Scheneider R, Hibbard HH. Survey of animal neoplasms in Alameda and Contra Costa Counties, Calif.:II. Cancer morbidity in dogs and cats from Alameda County. Journal of the National Cancer Institute 1968;40 307-318.

[3] Schneider R, Dorn CR, Taylor D. Factors influencing canine mammary tumor development and postsurgical survival. Journal of the National Cancer Institute 1969;43 1249-1261. 
[4] Kwapien RP, Giles RC, Geil RG, Casey HW: Malignant mammary tumors in beagle dogs dosed with investigational oral contraceptive steroids. Journal of the National Cancer Institute 1980; 65 137-144.

[5] Giles RC, Kwapien RP, Geil RG, Casey HW. Mammary nodules in beagle dogs administered investigational oral contraceptive steroids. Journal of the National Cancer Institute 1978;60:1351-1364.

[6] Misdorp W. Progestagens and mammary tumours in dogs and cats. Acta Endocrinologica (Copenh) 1991;125 27-31.

[7] Stovring M, Moe L, Glattre E. A population-based case-control study of canine mammary tumors and clinical use of medroxiprogesterone acetate. Acta Pathologica, microbiologica, et immunologica Scandinavica (APMIS) 1997;105 590-596.

[8] Allen HL. Feline mammary hypertrophy. Veterinary Pathology 1973;10 501-508.

[9] Loretti AP, Ilha MR, Ordás J, Martín de las Mulas J. Clinical, pathological and immunohistochemical study of feline mammary fibroepithelial hyperplasia following a single injection of depot medroxyprogesterone acetate. Journal of Feline Medicine and Surgery 2005;7(1) 43-52.

[10] Mialot JP, Andre F, Martin PH, Cotard MP, Raynaud JP. Etude des recepteurs des hormones steroids dans les tummeurs mammaires de la chienne. I: mise en evidence, caracterisation et relation avec le type histologique. Recueil de Medicine Veterinaire $1982 ; 158 ; 215-221$.

[11] Parodi AL, Misdorp W, Mialot JP, Mialot M, Hart AA, Hurtrel M, Salomon JC. Intratumoral BCG and Corynebacterium parvum therapy of canine mammary tumours before radical mastectomy. Cancer Immunology Immunotherapy 1983;15(3) 172-7.

[12] Martin PM, Cotard M, Mialot JP, André F, Raynaud JP. Animal models for hormonedependent human breast cancer. Relationship between steroid receptor profiles in canine and feline mammary tumors and survival rate. Cancer Chemotherapy and Pharmacolgy 1984;12(1) 13-17.

[13] Sartin EA, Barnes S, Kwapien RP, Wolfe LG. Estrogen and progesterone receptor status of mammary carcinomas and correlation with clinical outcome in dogs. American journal of Veterinary Researche 1992;53 2196-2200.

[14] Manzel O, Wurm S, Ueberschär S, Hoppen H-O: Estrogen and Progesterone receptors in histologic sections of canine mammary tumours in correlation to histologic type: conference proceedings, September 28, 1995, Edinburgh, Unite Kindong, ECVP; 1995.

[15] Graham JC, O'Keefe DA, Gelberg HB. Immnunohistochemical assay for detecting estrogen receptors in canine mammary tumors. Am J Vet Res 1999;60(5) 627-630. 
[16] Geraldes M, Gärtner F, Schmitt F. Immunohistochemical study of hormonal receptors and cell proliferation in normal canine mammary glands and spontaneous mammary tumours. Veterinary Record 2000;146 403-406.

[17] Martin de las Mulas J, van Niel M, Millán Y, Blakenstein MA, van Mil F, Misdorp W. Immunohistochemical analysis of estrogen receptors in feline mammary gland benign and malignant lesions: comparison with biochemical assay. Domestic Animal Endocrinology 2000;18 111-125.

[18] Nieto A, Peña L, Pérez-Alenza MD, Sánchez MA, Flores JM, Castaño M: Immunohistologic detection of estrogen receptor alpha in canine mammary tumors: clinical and pathologic associations and prognostic significance. Veterinary Pathology 2000;37 239-247.

[19] Martin de las Mulas J, Niel MV, Millan Y, Ordas J, Blankenstein MA, Mil FV, Misdorp W: Progesterone receptors in normal, dysplastic and tumourous feline mammary glands. Comparison with oestrogen receptors status. Research in Veterinary Science 2002;72 153-161.

[20] de las Mulas J, Millán Y, Dios R. A prospective analysis of immunohistochemically determined estrogen receptor alpha and progesterone receptor expression and host and tumor factors as predictors of disease-free period in mammary tumors of the dog. Veterinary Pathology 2005;42 200-212.

[21] Millanta F, Calandrella M, Vannozzi I, Poli A. Steroid hormone receptors i normal, dysplastic and neoplastic feline mammary tissues and their prognostic significance. Veterinary Record, 2006;158(24) 821-4.

[22] Chang CC, Tsai MH, Liao JW, Chan JP, Wong ML, Chang SC. Evaluation of hormone receptor expression for use in predicting survival of female dogs with malignant mammary gland tumors. Journal of American Veterinary Medical Association. 2009;235(4) 391-396.

[23] Ferreira E, Bertagnolli AC, Cavalcanti MF, Schmitt FC, Cassali GD. The relationship between tumour size and expression of prognostic markers in bening and malignant canine mammary tumours. Veterinary and Comparative Oncology. 2009; 7(4) 230-5.

[24] Sassi F, Benazzi C, Castellani G, Sarli G. Molecular-based tumour subtypes of canine mammary carcinomas assessed by immunohistochemistry. BMC Veterinary Research. 2010; 65.

[25] Dolka I, Motyl T, Malicka R, Sapierzynsky E, Fabisiak M. Relationship between receptors for insulin-like growth factor-I, steroid hormones and apoptosis-associated proteins in canine mammary tumors. Polish Journal of Veterinary Sciences, 2011; 14(2) 245-251.

[26] Rosen PP, Oberman HA. Tumors of the mammary gland. Washington, D.C: Armed Forces Institute of Pathology; 1993. 
[27] Martín de las Mulas J, Rollón E, Millán Y, Ordás J, Carrasco L, Reymundo C Perineal leiomyoma expressing steroidal hormone receptors in a queen. Veterinary Record 2002;150(18) 578-9.

[28] Rollón E, Millán Y, Martín de las Mulas J. Effects of aglepristone, a progesterone receptor antagonist, in a dog with a vaginal fibroma. Journal of Small Animal Practice 1997;49 41-43.

[29] Guil-Luna S, Sánchez-Céspedez R, Millán Y, De Andrés FJ, Rollón E, Domingo V, Guscetti F, Martín de las Mulas J. Aglepristone decreases proliferation in progesterona receptor-positive canine mammary carcinomas. Journal of Veterinary Internal Medicine 2011;25(3) 518-523.

[30] Domingo V, De Andrés FJ, Rollón E, Millán Y, Guil-Luna S, Sánchez-Céspedes R, Linares N, Martín de las Mulas J. Clinical response of canine perianal adenomas to subcutaneous implants of Deslorelin: conference proceedings, March 24-26, 2011, Glasgow Annual Congress of European Society of Veterinary Oncology, Glasgow, England. 2011.

[31] Millán Y, Gordon A, de los Monteros AE, Reymundo C, de las Mulas JM. Steroid receptors in canine and human female genital tract tumours with smooth muscle differentiation. Journal of Comparative Pathology 2007;136 197-201.

[32] Gallardo F, Mogas T, Baró T, Rabanal R, Morote J, Abal M, Reventós J, Lloreta J. Expression of Androgen, Oestrogen $\alpha$ and $\beta$, and Progesterone Receptors in the Canine Prostate: Differences between Normal, Inflamed, Hyperplastic and Neoplastic Glands. Journal of Comparative Pathology 2007;136 1-8.

[33] Baulieu E-E., Mester J. Steroid hormone receptors. In: De Groot L.J., (ed.). Endocrinology. Philadelphia: W.B. Saunders Co.; 1989. p16-39.

[34] Greene GL, Nolan C, Engler JP, Jensen EU. Monoclonal antibodies to human estrogen receptors: Proceeding of the National Academic of Sciences of the USA. 77:5115-5119, 1980.

[35] Greene GL, Harris K, Bravo R, Kinders R, Moore B, Nolan C. Purification of T47D human progesterone receptor and immunochemical characterization with monoclonal antibodies. Molecular Endocrinology 1988;2 714-726.

[36] al Saati T, Clamens S, Cohen-Knafo E, Faye JC, Prats H, Coindre JM, Wafflart J, Caveriviere P, Bayard F, Delsol G. Production of monoclonal antibodies to human estrogen-receptor protein (ER) using recombinant ER (RER). International Journal of Cancer 1993;55 651-654.

[37] Goussard J. Paraffin section immunocytochemistry and cytosol-based ligand-binding assay for ER and PR detection of breast cancer: the time has come for more objectivity. Cancer Letters 1998;132:61-66.

[38] De Mascarel I, Soubeyran I, MacGrogan G, Wafflart J, Bonichon F, Durand M, Avril A, Mauriac L, Trojani M, de Coindre JM. Immunohistochemical analysis of estrogen 
receptors in 938 breast carcinomas. Concordance with biochemical assay and prognostic significance. Applied Immunohistochemistry 1995;3 222-231.

[39] MacGrogan G, Soubeyran I, de Mascarel I, Wafflart J, Bonichon F, Durand M, Avril A, Maurac L, Trojani M, Coindre JM. Immunohistochemical Detection of Progesterone Receptors in Breast Invasive Ductal Carcinomas. Applied Immunohistochemistry 1996;4 219-227.

[40] Allred DC, Harvey JM, Berardo M, Clark GM. Prognostic and predictive factors in breast cancer by immunohistochemical analysis. Modern Pathology 1998;11 155-168.

[41] Balaton AJ, Berthelot N, Cuadrado C, Fillon L, Galland I, Gilles C, Lemoine C, Lucas C, Taluau V. Antigenic retrieval using a pressure cooker. Annales de Pathologie 1996;16(4) 307-309.

[42] Goussard J. Value of detection of hormone receptors by biochemical and immunochemical methods in therapeutic decision for breast cancer. Bulletin du Cancer 1996;83(12) 1031-1036.

[43] Krecsak L, Micsik T, Kiszler G, Krenacs T, Szabo D, Jonas V, Csaszar G, Czuni L, Gurzo P, Ficsor L, Molnar B. Technical note on the validation of a semi-automated image analysis software application for estrogen and progesterone receptor detection in breast cancer. Diagnostic Pathology 2011; 6: 6. www.diagnosticpathology.org/ content/6/1/6

[44] Hammond ME, Hayes DF, Dowsett M, Allred DC, Hagerty KL, Badve S, Fitzgibbons PL, Francis G, Goldstein NS, Hayes M, Hicks DG, Lester S, Love R, Mangu PB, McShane L, Miller K, Osborne CK, Paik S, Perlmutter J, Rhodes A, Sasano H, Schwartz JN, Sweep FC, Taube S, Torlakovic EE, Valenstein P, Viale G, Visscher D, Wheeler T, Williams RB, Wittliff JL, Wolff AC. American Society of Clinical Oncology/College of American Pathologists guideline recommendations for immunohistochemical testing of Estrogen and Progesterone Receptors in Breast Cancer. Archives of Pathology and Laboratory Medicine 2010 134(6):907-22.

[45] Lana S.E., Rutteman G.R., Withrow S.J. Tumors of the mammary gland. In: Withrow, S.J \& MacEwen, B.R. (ed) Small Animal Clinical Oncology. Philadelphia, P.A.: Saunders; 2007. p455-477.

[46] Brodey RS, Goldschmidt HH, Roszel JR. Canine mammary gland neoplasms. Journal of the American Animal Hospital Association 1983;19 61-90.

[47] Madewell BR, Theilen GH: Tumors of the mammary gland. In: Theilen G.H., Madewell B.R., (ed). Veterinary Cancer Medicine. Philadelphia: Lea \& Febiger; 1987. p327-344.

[48] Skorupski KA, Overly B, Shofer FS, Goldschmidt MH, Miller CA, Sørenmo KU. Clinical characteristics of mammary carcinoma in male cats. Journal of Veterinary Internal Medicine 2005;19 52-55. 
[49] Hayes HM, Jr., Milne KL, Mandell CP. Epidemiological features of feline mammary carcinomas. Veterinary Record 1981;108 476-479.

[50] Arnesen K, Gamlem H, Glattre J, Grondalen J, Moe L, Nordstoga K. The Norwegian canine cancer register 1990-1998. Report from the project "Cancer in the dog". The European Journal of Companion Animal Practice 2001;11 159-169.

[51] Craig LE. Cause of death in dogs according to breed: a necropsy survey of five breeds. Journal of the American Animal Hospital Association 2001;37 438-443.

[52] Dorn CR, Don T, Scheneider R, Hibbard HH. Survey of animal neoplasms in Alameda and Contra Costa Counties, Calif.:II. Cancer morbidity in dogs and cats from Alameda County. Journal of the National Cancer Institute 1968;40 307-318.

[53] Schneider R, Dorn CR, Taylor D. Factors influencing canine mammary tumor development and postsurgical survival. Journal of the National Cancer Institute 1969;43 1249-1261.

[54] Overley B, Shofer FS, Goldschmidt MH, Sherer D, Sorenmo KU. Association between ovarihysterectomy and feline mammary carcinoma. Journal of Veterinary Internal Medicine 2005;19(4) 560-3.

[55] Giles RC, Kwapien RP, Geil RG, Casey HW. Mammary nodules in beagle dogs administered investigational oral contraceptive steroids. Journal of the National Cancer Institute 1978;60:1351-1364.

[56] Rutteman GR. Contraceptive steroids and the mammary gland: Is there a hazard? Breast Cancer Researche and Treatment 1992;23 29-41.

[57] Kwapien RP, Giles RC, Geil RG, Casey HW. Malignant mammary tumors in beagle dogs dosed with investigational oral contraceptive steroids. Journal of the National Cancer Institute 1980;65 137-144.

[58] Misdorp W, Romijn A, Hart AA. Feline mammary tumors: a case-control study of hormonal factors. Anticancer Research 1991; 11(5) 1793-1797.

[59] Burrai GP, Mohammed SI, Miller MA, Marras V, Pirino S, Addis MF, Uzzau S, Antuofermo E. Spontaneous feline mammary intraepithelial lesions as a model for human estrogen receptor- and progesterone receptor-negative breast lesions. BMC Cancer. 2010;10 156.

[60] Sobczak-Filipiak M, Malicka E: Estrogen receptors in canine mammary gland tumours. Polish Journal of Veterinary Sciences 2002;5 1-5.

[61] Mouser P, Miller MA, Antuofermo E, Badve SS, Mohammed SI. Prevalence and classification of spontaneous mammary intraepithelial lesions in dogs without clinical mammary disease. Veterinary Patholgy. 2010;47(2) 275-84.

[62] Millanta F, Caneschi V, Ressel L, Citi S, Poli A. Expression of vascular endothelial growth factor in canine inflammatory and non-inflammatory mammary carcinoma. Journal of Comparative Pathology. 2010;142(1) 36-42. 
[63] Toniti W, Buranasinsup S, Kongcharoen A, Charoonrut P, Puchadapirom P, Kasorndorkbua C. Immunohistochemical determination of estrogen and progesterone receptors in canine mammary tumors. Asian Pacific Journal of Cancer Prevention. 2009;10(5) 907-11.

[64] Millanta F, Calandrella M, Bari G, Niccolini M, Vannozzi I, Poli A. Comparison of steroid receptor expression in normal, dysplastic, and neoplastic canine and feline mammary tissues. Researche Veterinary Science 2005;79(3) 225-32.

[65] Brunetti B, Asproni P, Beha G, Muscatello LV, Millanta F, Poli A, Benazzi C, Sarli G. Molecular Phenotype in Mammary tumours of queens: correlation between primary tumour and lymph node metastasis. Journal of Comparative Pathology.2012 Jul 19.

[66] Kuiper GG, Enmark E, Pelto-Huikko M, Nilsson S, Gustaffson JA: Cloning of a novel receptor expressed in rat prostate and ovary. Proc Natl Acad Sci USA 1996;93 59255930.

[67] Mosselman S, Polman J, Dijkema R: ER-beta: identification and characterisation of a novel human estrogen receptor. FEBS Lett 1996;392 49-53.

[68] Martín de las Mulas J, Ordás J, Millán MY, Chacón F, De Lara M, Espinosa de los Monteros A, Reymundo C, Jover A. Immunohistochemical expression of estrogen receptor beta in normal and tumoral canine mammary glands. Veterinary Pathology 2004;41(3) 269-72.

[69] Illeraa JC, Perez-Alenza M, Nieto A, Jimenez MA, Silvana G, Dunner S, Peña L. Steroids and receptors in canine mammary cancer. Steroids 2006; 7(1) 541-548.

[70] Morris JS, Dobson JM, Bostock DE. Use of tamoxifen in the control canine mammary neoplasia. Veterinary Record 1993;133 539-542.

[71] Yamagami T, Kobayashi T, Takahashi K, Sugiyama M: Influence of ovariectomy at the time of mastectomy on the prognosis for canine malignant mammary tumours. Journal of Small Animal Practice 1996;37 462-464.

[72] Morris JS, Dobson JM, Bostock DE, O'Farrel E. Effect of ovariohysterectomy in bitches with mamary neoplasia. Veterinary Record 1998;142 656-658.

[73] Cappeletti V, Granata G, Miodini P, Coradini D, DiFronzo G, Cairoli F, Colombo G, Nava A, Scanziani E. Modulation of receptor levels in canine breast tumors by administration of tamoxifen and Etretinate either alone or in combination. Anticancer Research 1988;8 1297-1302.

[74] Wehrend A, Hospes R, Gruber AD. Treatment of feline mammary fibroadenomatous hyperplasia with a progesterone antagonist. Veterinary Record 2001;148 346-347.

[75] Martín de las Mulas J, Millán Y, Bautista MJ, Pérez J, Carrasco L. Oestrogen and progesterone receptors in feline fibroadenomatous change: an immunohistochemical study. Research in Veterinary Science 2000;67 15-21. 
[76] McEntee MC. Reproductive oncology. Clinical Techniques in Small Animal Practice 2002;17(3) 133-149.

[77] Brodey RS, Roszel JF. Neoplasms of the canine uterus, vagina, and vulva: a clinicopathologic survey of 90 cases. Journal of the American Veterinary Medical Association 1967;151 1294-1307.

[78] Tacher C, Bradley RI. Vulvar and vaginal tumors in the dog: a retrospective study. Journal of the American Veterinary Medical Association 1983;183 690-692.

[79] Cotchin E. Neoplasia in the cat. Veterinary Record 1957;69 425-434.

[80] Engle CG, Brodey RS. A retrospective study of 395 felilne neoplasms. Journal of the American Animal Hospital Association 1969;5 21-25.

[81] Herron MA. Tumors of the canine genital system. Journal of the American Hospital Association. 1983;19 981-994.

[82] Schmidt RE, Langham RF. A survey of feline neoplasms. Journal of the American Veterinary Medical Association 1967;151 1325-1328.

[83] Theilen GH., Madewell BR. Tumors of the urogenital tract. In: Theilen GH \& Madewell BR (ed) Veterinary Cancer Medicine. Philadelphia: Lea \& Febiger; 1979. p567-600.

[84] Withrow SJ., Susaneck, SJ. Tumors of the canine female reproductive tract. In: Morrow DA (ed) Current therapy in theriogenology. Philadelphia: WB Saunders; 1986. p521-528.

[85] Dow C. Ovarian abnormalities in the bitch. Journal of Comparative Pathology 1960;70 59-69.

[86] Cotchin E. Spontaneous uterine cancer in animals. British Journal of Cancer 1964; 18:209-27.

[87] Cotchin, E. Some tumors of dogs and cats of comparative veterinary and human interest. Veterinary Record 1959;71 1040-1054.

[88] Klein MK. Tumors of the female reproductive system. In: Withrow SJ. \& MacEwen EG. (ed) Small Animal Clinical Oncology. Philadelphia: Saunders Elsevier; 2001. p445-454.

[89] MacLachlan NJ, Kennedy PC. Tumors of the genital system. In: DJ Meuten (ed) Tumors in domestic animals. Iowa: Iowa State Press; 2002. p547-574.

[90] Frost D, Lasota J, Miettinen M. Gastrointestinal stromal tumors and leiomyomas in the dog: a histopathologic, immunohistochemical, and molecular genetic study of 50 cases. Veterinary Pathology 2003;40 42-54.

[91] Zhu X-Q, Shi Y -F, Cheng X -D, Zhao C -L, Wu Y -Z. Immunohistochemical markers in differential diagnosis of endometrial stromal sarcoma and cellular leiomyoma. Ginecologic Oncology. 2004;92 71-79. 
[92] McGinley KM, Bryant S, Kattine AA, Fitzgibbon JF, Googe PB. Cutaneous leiomyomas lack estrogen and progesterone receptor immunoreactivity. Journal of Cutaneous Pathology 1997;24 241-245.

[93] Kydd DM, Burnie AG. Vaginal neoplasia in the bitch: a review of 40 clinical cases. Journal of Small Animal Practice 1986;27 255-263.

[94] Espinosa de los Monteros A, Millán Y, Ordás J, Carrasco L, Reymundo C, Martín de las Mulas J. Immunolocalization of the smooth muscle-specific protein calponin in complex and mixed tumors of the mammary gland of the dog: assessment of the morphogenetic role of the myoepithelium. Veterinary Pathology 2002;39 247-256.

[95] Galac D, Kooistra HS, Dielemn SJ, Cestnik V, Okkens AC. Effecs of aglepristone, a progesterone receptor antagonist, administered during the early luteal phase in nonpregnant bitches. Theriogenology 2004;62 494-500.

[96] Hayes HM, Pendergrass TW. Canine testicular tumors: epidemiologic features of 410 dogs. Internal Journal of Cancer 1976;18 482-487.

[97] Carpenter JL., Andrews LK., Holsworth J. Tumors and tumor-like lesions. In: Holzworth J. (ed) Diseases of the cat. Philadelphia:WB Saunders; 1987. p406-459.

[98] Bell FW, Klausner JS, Hayden DW, Feeney DA, Johnston SD. Clinical and pathologic features of prostatic adenocarcinoma in sexually intact and castrated dogs: 31 cases (1970-1987). Journal of the American Veterinary Medical Association 1991;199 1623-1630.

[99] Obradovich J, Walshaw R, Goullaud E. The influence of castration on the development of prostatic carcinoma in the dog: 43 cases (1978-1985). Journal of Veterinary Internal Medicine 1987;1 183-187.

[100] Caney SM, Holt PE, Day MJ, Rudorf H, Gruffydd-Jones TJ. Prostatic carcinoma in two cats. Journal of Small Animal Practice 1998;39 140-143.

[101] Hubbard BS, Vulgamott JC, Liska WD. Prostatic adenocarcinoma in a cat. Journal of the American Veterinary Medical Association 1990;197 1493-1494.

[102] LeRoy BE, Lech ME. Prostatic carcinoma causing urethral obstruction and obstipation in a cat. Journal of Feline Medicine and Surgery 2004;6 397-400.

[103] Ndiritu CG. Lesions of the canine penis and prepuce. Modern Veterinary Practice 1979;60 712-715.

[104] Lai CL, L'Eplattenier H, van den Ham R, Verseijden F, Jagtenberg A, Mol JA, Teske E. Androgen Receptor CAG repeat Polymorphisms in Canine Prostate Cancer. Journal of Veterinary Internal Medicine 2008;22 1380-1384.

[105] Cornell KK, Bostwick DG, Cooley DM, Hall G, Harvey HJ, Hendrick MJ, Pauli BU, Render, JA, Stoica G, Sweet DC, Waters DJ. Clinical and pathologic aspects of spontaneous canine prostate carcinoma: a retrosprective analysis of 76 cases. Prostate 2000;45 173-183. 
[106] Bell FW, Klausner JS, Hayden DV, Lund EM, Liebenstein BB, Feeney DA, Johnston SD, Shivers JL, Ewing CM, Isaacs WB. Evaluation of serum and seminal plasma markers in the diagnosis of canine prostatic disorders. Journal of Veterinary Internal Medicine 1995;9 149-153.

[107] Bonkhoff H, Fixemer T, Hunsicker I, Remberger K. Estrogen receptor expression in prostate cancer and premalignant prostatic lesions. American Journal of Pathology 1999;155 641-647.

[108] Vail DM.,Withrow SJ. Tumors of the mammary gland, In: Vail DM.,Withrow SJ (eds.) Small Animal Clinical Oncology. Philadelphia, WB Saunders; 2001. p455-477.

[109] Blackwood L. Tumours of the skin and subcutaneous tissues, In: Dobson JM., Lascelles BDX. (eds.) BSAVA Manual of canine and feline oncology. England, BSAVA ; 2011.p130-158.

[110] Kaldrymidou H, Leontides L, Koutinas AF. Prevalence, distribution and factors associated with the presence and potential for malignancy of cutaneous neoplasm in 174 dogs admitted to a clinic in northen Greece. Transboundary and emerging diseases 2002; 49(2) 87-91.

[111] Goldschmidt MH., Hendrick MJ. Tumors of the skin and soft tissues, In: Meuten DJ. (ed.) Tumors in domestic animals. EEUU, Iowa State Press; 2002. p45-119.

[112] Kariya Y, Moriya T, Suzuki T, Chiba M, Ishida K, Takeyama J, Endoh M, Watanabe $\mathrm{M}$, Sasano H. Sex steroid hormones receptors in human skin appendage and its neoplasms. Endocrine Journal 2005; 52(3) 317-325.

[113] Chaisiri N, Pierrpoint CG. Steroid-receptor interaction in a canine anal adenoma. Journal of Small Animal Practise 1979; 20(7) 405-416.

[114] Brakta-Robia CB, Egerbacher M, Helmreich M, Mitteregger G, Benesch M, Bamberg E. Immunohistochemical localization of androgens and oestrogen receptors in canine hair follicles. Veterinary Dermatology 2002; 13 (2) 113-118.

[115] Ginel PJ, Millán Y, Gómez-Laguna J. Localization of oestrogen and progesterone receptors in canine skin. Veterinary Dermatology 2006; 17 353-354 (Abstract).

[116] Frank LA, Donnell RL, Kania SA. Oestrogen receptor evaluation in Pomeranian dogs with hair follicle arrest (alopecia X) on melatonin supplementation. Veterinary Dermatology 2006; 17(4) 252-258.

[117] Ginel PJ, Lucena R, Millán Y, González-Medina S, Guil-Luna S, García-Monterde J, Espinosa de los Monteros A, Martín de las Mulas J. Expression of oestrogen and progesterone receptors in canine sebaceous gland tumors. Veterinary Dermatology 2009; 21 (3) 297-302.

[118] Bostock D. Neoplasm of the skin and subcutaneous tissues in dogs and cats. Brithis Veterinary Journal 1986; 142(1) 1-19. 
[119] Eigenmann JE, Poortman J, Koeman JP. Estrogen induced flank alopecia in the female dog, evidence for local rather than systemic hyperoestrogenism. Journal of the American Animal Hospital Association 1984; 20 (1) 621-624.

[120] Nielsen SW, Aftosmis J. Canine Perianal Gland Tumors. Journal of American Veterinary Medical Association 1964; 144(15) 127-135.

[121] Vail DM, Withrow SJ, Schwarz PD, Powers BE. Perianal adenocarcinomas in the canine male: a restrospective study of 41 cases. Journal of American Animal Hopital Association 1990; 26(3) 329-334.

[122] Turek, MM., \& Withrow, SJ. (2001). Perineal tumors, In: Vail DM.,Withrow SJ (eds.) Small Animal Clinical Oncology. Philadelphia, WB Saunders; 2001. P503-510.

[123] Isitor GN, Weinman DE. Origin and early development of canine circumanal glands. American Journal of Veterinary Research 1979; 40 (4) 487-492.

[124] Wilson GP, Hayes HM. Castration for treatment of perianal gland neoplasms in the dog. Journal of American Veterinary Medicine Association 1979; 174 (12) 1301-1303.

[125] Hayes HM, Wilson GP. Hormone-dependent neoplasms of the canine perianal gland. Cancer Research 1977; 37 (1) 2068-2071.

[126] Pisani G, Millanta F, Lorenzi D, Vannozzi I, Poli A. Androgen receptor expression in normal, hyperplastic and neoplastic hepatoid glands in the dog. Research in Veterinary Science 2006; 81 231-236.

[127] Elling H, Ungemach FR. Sexual hormone receptors in canine mast cell tumour cytosol. Journal of Comparative Pathology 1982; 92 629-630.

[128] Larsen AE, Grier RL. Evaluation of canine mast cell tumors for presence of estrogen receptors. American Journal of Veterinary Research 1989; 50 1779-1780. 